\title{
Early marginalist ideas on money: some neglected exceptions to the quantity theory
}

\author{
GERMÁN D. FELDMAN \\ National University of Quilmes
}

\begin{abstract}
The quantity theory of money (QTM) is an important building block of neoclassical economics. This has led scholars to believe that all monetary accounts proposed by marginalist economists are inherently based on the QTM. However, within the bimetallic controversy of the last quarter of the 19th century, there were some neoclassical proposals which departed from the framework of the QTM. In this article, I analyse three of these accounts: Alfred Marshall's symmetallism, Irving Fisher's compensated dollar plan, and Knut Wicksell's inconvertible paper standard. These monetary arrangements-especially the first two of them-have rarely been studied in the literature. Still, their relevance should not be neglected in current times in which the economics profession-both orthodox and heterodox approaches-has moved towards an endogenous money view. The proposals studied also show that the neutrality of money does not necessarily imply the QTM, as it is often suggested.
\end{abstract}

Keywords: bimetallic controversy, marginalism, monetary regimes, quantity theory, compensated dollar, symmetallism

JEL Classification: B13, E13, E31, E42

The establishment of a greater, and if possible absolute, stability in the value of money has thus become one of the most important practical objectives of political economy. But, unfortunately, little progress towards the solution of this problem has, so far, been made (Wicksell 1975 [1935], 7-8).

As can be appreciated in this quotation from a famous neoclassical economist, the first decades of marginalism in economics witnessed a

AUTHOR's Note: I am grateful to Bertram Schefold, Luis Mireles-Flores, and two anonymous referees for helpful comments and suggestions. I also thank the financial support of the National Council of Scientific and Technical Research of Argentina (CONICET) and the German Academic Exchange Service (DAAD). Any remaining errors are my responsibility. 
strong interest in discussions on monetary stability. Specifically, the objective to stabilise the average price level led scholars to postulate and debate alternative schemes to the prevailing gold standard system. Before the marginalist revolution, the notion of price stability in classical political economics consisted in keeping constant the purchasing power of money in terms of gold (or silver) - the standard of money under a metallic regime. Changes in the bullion price of commodities resulting from variations in mining costs were considered as "natural" and "inevitable" fluctuations (Ricardo 2004 [1810-1811], 65).

To deal with such short-run price fluctuations, the Peel's Act (1844) was implemented in Britain. This Act divided the issuing and banking functions of the Bank of England into two independent bodies with the aim of bringing the gold standard to a sound basis according to the classical account. The Peel's Act was meant as an application of the so-called 'currency principle' to rule out over-expansionary bias of monetary policy. According to the 'currency principle', in order to achieve a 'sound' currency, gold movements should be entirely reflected in domestic circulation, limiting thereby the capacity of the banking system to expand the money supply through credit operations. ${ }^{1}$

After the marginalist revolution, monetary theorists-now equipped with a marginalist framework and holding a notion of price stability that implied the constancy of money prices-moved one step forward from the classical approach and tried to eliminate the remaining factor believed to induce permanent price fluctuations, the gold standard system. ${ }^{2}$ A crucial difference between the classical and the marginalist views is that to the former, prices including those of precious metals are determined by the costs of production (leading to an endogenous view of money), while to the latter, income distribution and long-term prices are determined by supply and demand conditions (leading to an exogenous view of money).

The new marginalist proposals conferred a special role to the quantity theory of money (QTM). As is well known, in general equilibrium models relative prices, production levels, and 'factor rentals'

\footnotetext{
${ }^{1}$ During the currency and banking schools debate that prevailed after the 1820s, the 'currency principle' was at the core of the dispute. The principle was strongly endorsed and defended by the school of Robert Torrens and Samuel Lloyd Jones, whereas it was opposed by the doctrine of Thomas Tooke and John Fullarton, who were ardent critics of the principle.

${ }^{2}$ In effect, the international gold standard proved unable to ensure price stability, as J. Laurence Laughlin (1909) documents for the last quarter of the 19th century, which registered periods of prolonged deflation and inflation.
} 
(i.e., the real wage and the rate of interest) are firstly determined in the 'real sector' of the economy. This sector tends to full employment of resources, pushed by the substitution effect, and hence all nominal variables are established independently in the monetary sphere of the system once the quantity of money in circulation is specified. The QTM, though it originated much prior to the marginalist era, emerged as a suitable monetary-side counterpart to the neoclassical 'barter-exchange' description of market economies.

As a consequence of the use of the QTM as a key element in the neoclassical account, it is commonly believed that the founders of marginalism always argued on the basis of the QTM. For instance, Don Patinkin (1948; and 1965) states that the so-called 'real-monetary dichotomy' resided at the core of the contributions of Walras, Marshall, Wicksell, and basically most authors writing prior to the 1930s. Similarly, it is generally agreed that Marshall was a quantity theorist (see Humphrey 2004); and the prevailing view about Irving Fisher-primarily based on The purchasing power of money (1997 [1913]) - is that he gave the QTM its modern shape (see Dimand 2000).

There are, however, three proposals endorsed by neoclassical authors that are exceptional in that they are founded on an endogenous view of money and are independent of the QTM, namely Alfred Marshall's symmetallism, Irving Fisher's compensated dollar, and Knut Wicksell's inconvertible paper standard. These accounts have been seldom explored in the literature, with the possible exception of Wicksell's contribution. Yet, a detailed analysis of these proposals is relevant for at least two reasons: First, the economics profession-both the orthodox and heterodox approaches-has moved towards an endogenous money perspective as a more realistic description of modern economies (which is commonly thought to be in itself a move away from neoclassical economics). ${ }^{3}$ Second, the study of these exceptional cases can establish new links between the marginalist view and the classical tradition, in which money was also conceived as an endogenous magnitude under a metallic or credit standard.

With the aim of exploring such monetary arrangements, this article is structured as follows. Section 1 discusses monetary regimes based on the validity of the quantity theory of money. The focus is placed on standard bimetallism, which represented the main rival to the gold

\footnotetext{
${ }^{3}$ This trend can be appreciated, e.g., from the contributions to the new macroeconomic consensus or the post-Keynesian doctrine.
} 
standard. Section 2 explores the three alternative schemes that emerged directly from the neoclassical school, but that are exceptional in that they departed from the QTM framework. The final section offers some concluding remarks.

\section{MONETARY REGIMES ROOTED IN THE QUANTITY THEORY OF MONEY}

The point of departure for the discussion of monetary regimes alternative to the gold standard can be traced to the 'Bimetallic controversy', which developed between the defenders of monometallic and those of bimetallic standards during the last quarter of the 19th century. ${ }^{4}$ At the empirical level, the experience of France, which at least de jure had successfully maintained a bimetallic system since the end of the Napoleonic wars to the $1870 \mathrm{~s},{ }^{5}$ served as inspiration for probimetallism. This view highlighted the stability of the relative price between gold and silver and of the exchange rate between countries with the gold standard and the silver standard during that period (especially between England and India).

In contrast to this steadiness observed in some instances, the last decades of the 19th century were characterised by a marked exchange rate instability and a generalised world deflation (the Great Depression). ${ }^{6}$ Its roots, in the opinion of bimetallists, had to be found in the insufficient performance of the world gold supply when compared with a fast-growing bullion demand from economies experiencing a transition towards a gold standard and the rise of world aggregate output. $^{7}$ In this section I present the classical qualms against

\footnotetext{
${ }^{4}$ The Bimetallic controversy can be considered as the third big monetary controversy of the century, after the Bullionist controversy (i.e., the debates of the British Restriction Period (1797-1821) on the convenience of a commodity standard vis-à-vis inconvertible paper money), and the currency and banking schools' controversy on the normal working of a convertibility system in the 1830 s and 1840 s.

${ }^{5}$ The scope of bimetallism was extended from France to its neighbours, when in 1865 the French government in company of Belgium, Switzerland, and Italy formed the Latin Monetary Union.

${ }^{6}$ It should be noted that the term 'Great Depression' is not entirely adequate, since despite deflation, output and real wages continued to move upwards at "impressive rates" (Rostow 1947, 58).

${ }^{7}$ In contrast, W. W. Rostow explains the declining trend of output prices by the rise of productivity in the British economy. The author also mentions, with a Kaleckian flavour, the possibility that lower profits and prices were explained by a decrease of the 'degree of monopoly' in the British economy after 1873 due to the rapid development of capital industries, among other factors, in the United States and Germany, and the existence of idle capacity when fixed investments matured, inducing domestic price-cutting competition (Rostow 1947, 233).
} 
bimetallism in contrast to standard neoclassical proposals that were rooted in the QTM.

\section{The classical view against bimetallism}

Two opposite views on the long-period viability of standard bimetallism can be found in the literature. On the one hand, the classical school, ${ }^{8}$ endorsing a cost-of-production determination of the relative price of gold in terms of silver, considered that bimetallism was intrinsically unstable. Specifically, it faced a 'knife-edge' problem: if the official parity did not match the market ratio, the metal over-valued in the market would disappear from circulation, leading to a de facto monometallic standard. ${ }^{9}$ In effect, as David Ricardo expresses:

No permanent measure of value can be said to exist in any nation while the circulating medium consists of two metals, because they are constantly subject to vary in value with respect to each other. However exact the conductors of the mint may be, in proportioning the relative value of gold to silver in the coins, at the time when they fix the ratio, they cannot prevent one of these metals from rising, while the other remains stationary, or falls in value. Whenever this happens, one of the coins will be melted to be sold for the other. Mr. Locke, Lord Liverpool, and many other writers, have ably considered this subject and have all agreed, that the only remedy for the evils in the currency proceeding from this source, is in making one of the metals only the standard of value (Ricardo 2004 [1810-1811], 19-20; italics added)

Therefore, to classical authors, a bimetallic regime at a fixed parity $y^{10}$ would follow an unstable path affected by the operation of Gresham's law, once market conditions have changed from the initial levels used as a reference for setting the official parity.

Let us use a simple example presented by Laughlin $(1896,26)$ to understand its functioning. Initially, the mint and market ratio of gold

\footnotetext{
${ }^{8}$ For a description of the classical approach articulated along Sraffian lines, see Garegnani 1984; 1990; and Eatwell 1977.

${ }^{9}$ Of course, the market ratio may permanently depart from the mint ratio between the boundaries imposed by the 'gold-silver' points in a similar way to the operation of a gold standard.

${ }_{10}$ Once symmetallism is introduced into the picture, the references to 'standard' bimetallism or bimetallism 'at a fixed parity' will become much clearer. Put it shortly, the conventional approach to a double standard implies arbitrary fixing the parity between gold and silver, while an alternative option could be to define the quantity ratio or the composition of coins, while leaving the value ratio to be set by market conditions.
} 
relatively to silver are both 1:15, but market conditions change and the new relative price becomes 1:16. That is, in the market it requires sixteen ounces of silver to buy one ounce of gold bullion; but at the Mint the Government receives fifteen ounces of silver, and coins it into silver coins which are legally equivalent to one ounce of gold. The holder of silver will be tempted to bring his silver to the Mint and exchange it for silver coins. The money brokers, who are better informed than the general public about the value of metals, lead the arbitrage process. They exchange the silver coins obtained from the Mint for gold coins as long as gold coins remain in circulation. Having received an ounce of gold in coin for their fifteen ounces of silver coin, they can at once sell the gold as bullion (after melting it, or selling it to exporters) for sixteen ounces of silver bullion. They retain one ounce of silver as profit, and with the remaining fifteen ounces of silver go to the Mint for more silver coins, repeating the whole process. And thus, as Laughlin puts it:

The existence of a profit in selling gold coins as bullion, and presenting silver to be coined at the Mint, is due to the divergence of the market from the legal ratio, and no power of the Government can prevent one metal from going out of circulation $(1896,27)$.

In a similar vein, T. Lloyd $(1894,35)$ argues that during its seventy years of formal existence, French bimetallism was never operative. Both gold and silver never circulated at the same time. Up to 1848 France was a silver-using country; afterwards it became gold-using. ${ }^{11}$ And Willis (1895) provides evidence of Gresham's law indeed operating in France during the bimetallic period.

\section{The marginalist view in favour of bimetallism}

Early marginalist authors such as Walras (1977 [1874]), Marshall (1923 [1887]) and Fisher (1894), ${ }^{12}$ defended bimetallism based on the validity

\footnotetext{
${ }^{11}$ However, Lloyd remarks the positive effects of bimetallism, which, though not sustainable, was a natural transition from a silver standard, which characterised European countries before the 19th century, to the gold standard, which dominated by the end of the 19th century (Lloyd 1894, 31-32).

${ }^{12}$ As an exception, Jevons was a declared gold monometallist who held an optimistic view of the responsiveness of world gold supply and stressed the lower bulk of gold as money vis-à-vis silver, especially for countries experiencing a growing wealth. It is quite remarkable that the author-though sharing with Walras and Marshall a theory of value and distribution based on marginal utility-remained much closer to the classical tradition with regard to the treatment of the value of money under a commodity standard: "the value of gold and silver are ultimately governed, like those of all commodities, by the cost of production" (Jevons 1886 [1881], 100). Jevons, like
} 
of the quantity theory of money (see Laidler 2004). In contrast to the use given to it by classical authors, the QTM was then not only applied to the case of inconvertible paper money, but also to a metallic circulation. Neoclassical economists believed that the instauration of an official parity between gold and silver did not imply replacing a 'natural' value with an 'artificial' discretionary ratio, but filling in a gap left by the market due to the specificities of precious metals:

[...] gold and silver have no natural value. They are so durable that the year's supply is never more than a small part of the total stock, and therefore their values do not conform closely to their costs of production. And, in so far as their values are regulated by the relations between the demands for them and the existing stocks of them, their value is artificial, because the demand for them as currency is itself artificial (Marshall 1923 [1887], 200-201).

Fisher's exposition of a bimetallic standard allows comparing the classical and neoclassical views on the subject in order to establish theoretical and methodological differences. Fisher stresses that market prices are slow in their gravitation towards normal prices in the case of precious metals due to the slow adjustment of supply. As a result, two different equilibriums arise: a 'temporary equilibrium', with a given stock of precious metals, and a 'normal or permanent equilibrium', with an endogenous stock of gold and silver (see Fisher 1997 [1913], 124).

To see this more clearly, consider the following general equilibrium model. Let us assume an economy with $n>2$ commodities, including gold $(g)$ and silver $(s)$. Land is free and joint production is excluded. Commodity $j$ (with $j \neq g, s$ ) is employed as the numéraire of the price system $\left(p_{j}=1\right)$. Long-period or normal prices for consumption and

Ricardo and his followers, employed the quantity theory only as a short-run adjustment mechanism. In the long period, "the common argument that there will not be enough gold to carry on the trade of the world with, does not stand a moments' examination in this aspect. In the first place, if the value of gold rises, more gold will be produced, and the great number of gold-mining enterprises now being put forth may have some connection with this principle" (Jevons 1886 [1881], 100). To which he adds: "When we turn to the temporary view of the subject, by which I mean the circumstances and interests of the next ten or fifteen years, the difficulties increase, chiefly because the data become wholly uncertain and contingent. The great principle of the cost of production fails us, because in the case of such durable commodities as gold and silver, the accumulated stock in hand is immensely greater than the annual production or consumption. It stands to reason, of course, that if several great nations suddenly decide that they will at all cost have gold currencies to be coined in the next few years, the annual production cannot meet the demand, which must be mainly supplied, if at all, out of stock" (Jevons 1886 [1881], 102). 
capital goods (i.e., excluding precious metals) are defined by the following $(n-2)$ conditions:

$$
p_{i / j}=c_{i}^{13}
$$

The quantity system includes $n$ market-clearing conditions: ${ }^{14}$

$$
Q_{i}^{d}\left(p_{i / j}, \ldots, p_{n / j}\right)=Q_{i}^{s}\left(p_{i / j}, \ldots, p_{n / j}\right)
$$

Let us note that the demands for gold and silver emerging from the general equilibrium system only reflect their industrial or non-monetary uses $\left(Q_{g b}^{d}\right.$ and $\left.Q_{s b}^{d}\right)$. The quantity of gold and silver circulating as money will therefore result from deducing the industrial demand from the given stock of precious metals $\left(\bar{Q}_{g}^{s}, \bar{Q}_{s}^{s}\right)$ :

$$
\begin{aligned}
Q_{g}^{d} & \equiv Q_{g b}^{d}+Q_{g M}=\bar{Q}_{g}^{s} \\
Q_{s}^{d} & \equiv Q_{s b}^{d}+Q_{s M}=\bar{Q}_{s}^{s}
\end{aligned}
$$

As has been previously mentioned, the implementation of a bimetallic system implies that some proportion of both metals must circulate simultaneously as money. Therefore, the following two restrictions must be added:

$$
\begin{aligned}
& Q_{g M}=Q_{g}-Q_{g b}>0 \\
& Q_{s M}=Q_{s}-Q_{s b}>0
\end{aligned}
$$

Finally, monetary prices will result from the 'exchange equation', which reflects that the value of transactions performed in a certain period must necessarily be sustained by an equivalent amount of circulating medium:

\footnotetext{
${ }^{13}$ In this expression, $c_{i}$ is defined by the normal cost of production of commodity $i$, which reflects the dominant technique and the state of income distribution. Assuming constant returns to scale demand conditions will influence natural prices only through their effect on normal distribution.

${ }^{14}$ For simplicity, the market clearing conditions for the factors of production (labour and capital) are omitted from the analysis, but a complete version of the general equilibrium system should include them in order to find the equilibrium values of the wage rate and the rate of interest (profits).
} 


$$
\frac{1}{v}\left(\sum_{i=1}^{n-2} p_{i / j} Q_{i}\right) p_{j / g}=Q_{g M}+p_{s / g} Q_{s M}
$$

Where:

$$
\begin{aligned}
& v=\text { 'normal' }{ }^{15} \text { velocity of circulation } \\
& p_{s / g}=\text { price of silver in terms of gold }
\end{aligned}
$$

As can be seen from (5), the 'exchange equation' determines the gold price of commodities $\left(p_{j / g}\right)$, once the relative price between gold and silver is set 'from outside', ${ }^{16}$ in line with the QTM, whose central elements are an exogenous money supply and an endogenous price level.

There was a general consensus among the advocates of bimetallism on the fact that for a small open economy, viz. one that faced a given gold-silver ratio in the rest of the world, bimetallism at an official parity that is different from the international parity could not be permanently maintained. This is so because of the operation of arbitrageurs exploiting the profits of bullion trade. The emphasis of pro-bimetallists on international cooperation in monetary matters can therefore be easily grasped: ${ }^{17}$

But let us suppose for the sake of argument 'one metal or the other' to be the dearer of the two, and that therefore it 'will leave the country', and the depreciated metal will remain. It is admitted on all

\footnotetext{
15 As Mauro Caminati (1981) suggests, important changes in the composition of demand for monetary assets tended to be confined to periods of alarm when the state of confidence collapsed. In normal times, the ratio of the demand for gold and banknotes to monetary income tended to be relatively stable.

${ }^{16}$ Neither Walras nor Fisher believed that the gold-silver ratio could be freely set disregarding market conditions derived from their uses in art and industry. Indeed, there was a range of values in which bimetallism was possible, defined by the relative prices that would be effective under monometallic gold and silver standards. "The legislator may undoubtedly announce an arbitrary ratio of value between gold and silver; but what he cannot do is ensure that this ratio is kept up, or even that it will become established if it deviates too far from a certain value in line with the actual circumstances. If this legal value were too high, i.e., too much to the advantage of gold, then all silver would remain in the form of merchandise and, in fact, the legislator would decree gold monometallism; if it were too low, i.e., too much to the advantage of silver, then gold would remain in the form of merchandise and, in fact, the legislator would have decreed silver monometallism" (Walras 2005 [1884], 117).

17 The defenders of French bimetallism thus considered that France, though surrounded by economies with other gold-silver ratios, concentrated a high proportion of the world stock of precious metals, so that its domestic conditions could influence their international values.
} 
hands that such was the case with France when she stood alone a bimetallic nation surrounded by monometallic neighbours; and that such must be the case with any single country so standing. It must with equal unanimity be admitted that if all commercial nations without exception had but one mind in the matter and received Gold and Silver alike (in a fixed proportion) in payment of debt, no such exodus of one or other could take place. Whither would the dearer metal go? Surely the objectors will not say that it will leave all countries simultaneously! (Gibbs 1886 [1881], 40).

Nevertheless, it is clear-from a marginalist perspective-that a closed economy with gold and silver mining, as well as the world economy as a whole, could implement bimetallism without major inconveniences. To Gibbs, gold and silver in these cases are in fact two complementary parts of the same whole:

Under such a compact, Silver and Gold are as one metal-limbs of the same body, parts of the same whole-fused like an electrum into one mass; and when both are recognized as the measure of other commodities, whose value as a mass varies with the total quantity of that measure, the cost of production does not practically determine the mutual value of the two parts of it (Gibbs 1886 [1881], 39).

To sum up, a critique of bimetallism as a permanent monetary regime should call into question the validity of a double standard within the boundaries of a closed economy. The 'market ratio' should have a meaning beyond the official parity in different countries. The key issue in relation to the feasibility of bimetallism is the role of the exchange ratio between gold and silver defined by costs equations. Only if the flow of annual production and thus the costs of production are placed at the core of the supply side of gold and silver, can bimetallism be fundamentally criticized. Only if bullion mining yields the average rate of profits, can productive capitals be directed to it and a regular flow of production necessary for reproducing the system be granted. If the mint ratio, for instance, undervalues silver, then capital will leave silver mining and flow to other branches of production where a higher rate of profits can be obtained. The fundamental flaw of standard bimetallism would be thus the attempt to fix two numéraires, hence overdetermining the normal price system. ${ }^{18}$

\footnotetext{
${ }^{18}$ As Piero Sraffa (1960) masterfully shows, once one distributive variable is specified, there is only room to set one numéraire (this fact does not rule out the possibility of choosing the price of a bundle of commodities).
} 


\section{Fisher's solution and Walras's alternative}

Following Pierangelo Garegnani (1976), one could assimilate the normal equilibrium of Fisher to the long-period equilibrium of classical economists. ${ }^{19}$ Under a permanent equilibrium, the cheap metal pushes the dear one out of circulation, destroying bimetallism as Ricardo formerly suggested. However, according to Fisher, the physical properties of precious metals and the specificities of their supply make temporary and normal equilibriums quite distinctly separated in time:

The time of redistributing existing stocks of metal, according to a newly enacted law, depends on the rapidity of transportation, melting, and minting, and would be measured in months or weeks. Normal equilibrium, however, depends on the slow working of changes in the rates of production and consumption, and would be measured in years (Fisher 1997 [1913], 124)

In the meantime, counterbalancing forces may arise, such as changes in the conditions of production of the dear metal, so as to revert the natural price towards the official parity. In other words, while the normal equilibrium could be relevant in theoretical terms, its existence being enough to challenge the viability of bimetallism, it could be disregarded in practical terms, since before converging to such a position the economy may adopt a different path.

A further illustration of a monetary regime relying on the QTM is Walras's gold standard with restrictive minting of silver (2005 [1884]). Such a scheme represented an intermediate position between a double standard and gold monometallism. On the one hand, this system held with bimetallism the coexistence of gold and silver as circulating media. On the other, it shared with the gold standard the fact that gold alone had a fixed price, while silver was a mere token, with its purchasing power as a coin being higher than its value as a commodity. Under this arrangement, the government would be able to expand or contract the money supply in order to stabilize the price level. In Walras's terms:

The State will increase or decrease its quantity according to the circumstances. If the rareté and, consequently, the value of money

\footnotetext{
${ }^{19}$ Garegnani argues that neoclassical theory until the mid-1930s shared with classical economics the implied notion of equilibrium, which was understood as a long period position in which prices are such so as to allow a uniform rate of profit over supply prices.
} 
tend to climb over the limit assigned to it, the quantity of the special token should be increased. This would allow for the demonetization of a certain quantity of gold, reducing the rareté and the value of the money commodity. If the rareté and, consequently, the value of money tended to remain below the limit, the quantity of special token should be lowered. This would entail the monetization of a certain quantity of gold and increase the rareté and value of the money commodity (Walras 2005 [1884], 8).

In this respect, over-valued silver would not displace gold from circulation, because the mint would not be open to the free coinage of silver. Thus the government would be the agent in charge of buying silver bullion in the market at the prevailing price and subsequently coining the metal, rather than arbitrage decisions of the private sector.

\section{NEOCLASSICAL REGIMES NOT BASED ON THE QUANTITY THEORY OF MONEY}

There exist some neglected exceptions among neoclassical scholars to the usual recourse to the QTM when exploring commodity standards. Although it may seem surprising to some at first glance, monetary regimes that are independent of the QTM are a possibility within the marginalist framework. This is so because a general equilibrium system is compatible with an endogenous stock of precious metals and a natural value of bullion defined by the costs of production, rather than relative scarcity. ${ }^{20}$

In terms of the general equilibrium model described in the previous section, two relevant changes have to be made. First, the system of normal prices should include the cost-of-production equations for gold and silver, resembling those of other reproducible commodities. In this case gold is taken as the numéraire:

$$
\begin{aligned}
p_{i / g} & =c_{i} \quad(i=1 \ldots n-1) \\
1 & =c_{g}
\end{aligned}
$$

Secondly, since the relative price between gold and silver $\left(p_{s / g}\right)$ comes to be defined by structural conditions in $\left(1^{\prime}\right),{ }^{21}$ the 'exchange equation' will be interpreted now as determining the equilibrium quantity of money. As the new interpretation of equation (5) reveals, an additional condition must be introduced in order to define the monetary

\footnotetext{
${ }^{20}$ See Jürgen Niehans 1978, chapter 8.

${ }^{21}$ See footnote 13.
} 
demand for each precious metal under a bimetallic standard. Specifically:

$$
Q_{g M}=\bar{k} Q_{s M}
$$

With $k$ an arbitrary constant setting the composition of the money stock. As will be discussed in the following subsection, there is an alternative to bimetallism proposed by Alfred Marshall, called symmetallism, which precisely provides the required condition.

\section{Marshall's symmetallism}

The symmetallic system exposed by Alfred Marshall in his essay "Remedies for fluctuations in general prices" (1923 [1887])—which according to the British scholar found inspiration in Ricardo's Ingot plan-represents a variant of a bimetallic standard that fixes the quantity ratio, instead of the value ratio. This is how he describes it:

I propose that currency should be exchangeable at the Mint or Issue Department not for gold, but for gold and silver, at the rate of not $£ 1$ for 113 grains of gold, but $£ 1$ for $561 / 2$ grains of gold, together with, say, twenty times as many grains of silver. I would make up the gold and silver bars in gramme weights, so as to be useful for international trade. A gold bar of 100 grammes, together with a silver bar, say, twenty times as heavy, would be exchangeable at the Issue Department for an amount of the currency which would be calculated and fixed once for all when the scheme was introduced. (It would be about $£ 28$ or $£ 30$ according to the basis of calculation.) Any one who wanted to buy or sell gold or silver alone in exchange for currency could get what he wanted by exchanging gold for silver, or silver for gold, at the market rate. Government fixing its own rates from day to day, so as to keep its reserves of the two metals in about the right proportion, might safely undertake this exchange itself; and then any one could buy or sell either gold or silver for currency in one operation (Marshall 1923 [1887], 204-205).

At the time of the introduction of this proposal, it was presented as a variant but equivalent alternative to the typical bimetallism with a fixed value ratio. ${ }^{22}$ Nevertheless, the fact that symmetallism does not aim at imposing an arbitrary relative price makes this arrangement

\footnotetext{
${ }^{22}$ Indeed, as Walras (1977 [1874], 339) shows, in a general equilibrium system with a bimetallic monetary standard, there are $n$ independent equations to solve for $n+1$ variables, so that there exists one degree of freedom.
} 
potentially compatible with the classical approach. In effect, a 'classical' bimetallic standard would imply a metallic circulation of coins whose technique of production employed fixed quantities of gold and silver as inputs, or a circulation of paper money convertible on demand into certain quantities of gold and silver bullion:

$$
p_{m / g}=\left(b_{m}^{g}+b_{m}^{s} p_{s / g}\right)=1
$$

Where:

$$
\begin{aligned}
& p_{m / g}=\text { value of a coin }(m) \text { in terms of gold bullion } \\
& b_{m}^{g}=\text { quantity of gold bullion necessary to produce one coin } \\
& b_{m}^{s}=\text { quantity of silver bullion necessary to produce one coin }
\end{aligned}
$$

The purchasing power of such money would be defined by its respective cost of production. In addition, the symmetallic standard would be more stable than a monometallic standard, because the depreciated metal would erode the value of money only by its weight on the composite commodity. ${ }^{23}$ At the same time, the value of the coin would be subject to more regular fluctuations for it would change with every change in value of either of the two metals, instead of only one (see Miller 1898, 276).

Indeed if the bimetallists had changed two single words in their formulation they would have been proposing something better than the gold standard instead of something worse. If instead of saying, "Let a dollar stand for 25.8 grains of gold or 412.5 grains of silver" they had said, "Let two dollars stand for 25.8 grains of gold and 412.5 grains of silver", and if this proposal had been adopted, then some of the more serious fluctuations in prices could have been avoided (see Lewis 1925, 42).

In other words, Marshall's proposal aims to ensure a double standard, but avoid the intrinsic instabilities connected with the attempt to arbitrarily fix a relative price between two commodities.

\footnotetext{
${ }^{23}$ Marshall's symmetallism was later extrapolated into schemes that included a larger number of commodities. For instance, Benjamin Graham (1937) proposed that the dollar should be defined in terms of a fixed-weight basket of 23 commodities, and that the Federal Reserve issue notes against warehouse receipts for the basket thus established. He selected his commodities on the strength both of their economic importance and their storability. Simultaneously but independently, Frank Graham (1949) advocated a similar plan.
} 


\section{Fisher's compensated dollar}

Irving Fisher's plan for a 'compensated dollar' was confined to a gold standard system and therefore, was less radical than Marshall's proposal, in that it implied continuity with the most common monetary regime of the time. It intended to neutralise changes in the gold price of commodities by counterbalancing variations in the official price of gold, thus leaving the general price level as constant. This is Fisher's presentation of his proposal:

The plan aims to make the purchasing power of the dollar constant. It would compensate for any loss of purchasing power of each grain of gold by increasing the number of grains which go to make a dollar. In other words it aims to standardize the dollar as a unit of purchasing power. We have standardized the yard, the pound, the kilowatt, and every other important commercial unit except the most important of all, the dollar, the unit of purchasing power. We have now a gold dollar of constant weight, but of varying purchasing power. We need a dollar of constant purchasing power and varying weight (Fisher 1997 [1913], 214).

In terms of implementation, Fisher planned to manipulate the seigniorage rate on gold coinage ('seg' hereafter), readjusting it according to changes in the general price level. As commodity prices rose, the weight of the 'bullion dollar' or the normal value of money would be sustained by a rise of seg. "The increasing number of grains of bullion going to make a dollar would then compensate for the lessening purchasing power of each grain" (Fisher 1997 [1913], 218). Analytically:

$$
\begin{aligned}
& \bar{p}_{i / m}=\uparrow p_{i / g} \cdot \downarrow p_{g / m} \\
& \uparrow p_{m / g}=b_{m}(1+\uparrow \mathrm{seg})
\end{aligned}
$$

One possible objection to this arrangement is how to deal with a situation of falling prices instead of rising ones. Though a detailed analysis of the working of coinage is beyond the scope of the present inquiry, we know that the gold price of coins $\left(p_{m / g}\right)$ cannot fall below its natural level for an amount higher than the melting cost, for then all the gold coin will at once be melted into bullion, in which form it will be worth more than as coin. This fact is recognised by Fisher himself, who expresses that: "In a period of rising prices, regulation would be easy; in a period of falling prices, regulation might be quite impossible" 
(Fisher 1997 [1913], 331). In addition, John Maynard Keynes (1971 [1926], 126) considers that Fisher's plan implied "a preference for stability of internal price level over stability of external exchange". Furthermore, to periodically change the mint price of gold in order to offset fluctuations in the value of bullion would imply "the ultimate abandonment of gold as a monetary standard" (Cassel 1920, 43). ${ }^{24}$

The lack of any role for the QTM in Fisher's programme is explicitly recognized by the American scholar in a newspaper article: "there is nothing whatever in the plan to standardize the dollar which could not be accepted by those who reject the quantity theory altogether" (Fisher, New York Times, December 22, 1912). This fact astonished modern neoclassical authors such as Don Patinkin, who, far from attempting a logical critique of the proposal, provided instead an ad-hoc justification:

[...] the person who is our present concern is not Irving Fisher the author of the scientific work on The Purchasing Power of Money, but Irving Fisher the deviser of a plan to be 'sold' to the economics profession as well as to the business community and governmentand to be 'packaged' accordingly. The quantity theory of money was out of favour in some circles, so the plan should not be explicitly associated with it. The commodity theory of money had influential supporters, so the plan should be presented in language that had the sounds of that theory. The gold standard was sacred, so it should be emphasized that the plan did not involve its abandonment (Patinkin $1993,9){ }^{25}$

To sum up, Fisher's plan for a monetary regime (which was not rooted in the QTM) was essentially intended to offset the fluctuations in the value of gold with counterbalancing movements in the purchasing power of the unit of account.

\section{Wicksell's inconvertible paper standard}

As a step towards eliminating the long-period fluctuations of money prices induced by changes in the productivity of gold mines, Knut Wicksell advocated divorcing the monetary standard from precious

\footnotetext{
${ }^{24}$ The immediate consequence of achieving price stability would be the variability of the money price of gold. Yet, it should be noticed that the periodic redefinition of a fixed standard cannot be put on the same grounds of a fully flexible monetary regime. ${ }^{25}$ Interestingly, contemporary critics such as Frank Taussig $(1913,402)$ argue precisely the opposite, namely, that Fisher's proposal was designed to restrain the money supply and thus, to stabilize the general price level in a standard quantity-theoretic basis. In order to achieve such result, Taussig interprets the quantity of gold retained by the State as seigniorage as a reduction in the quantity of money in circulation.
} 
metals and from any other commodity, by introducing instead a 'managed' inconvertible paper currency. This is how Wicksell presents the significance of his proposal:

Only by completely divorcing the value of money from metal, or at any rate from its commodity function, by abolishing all free minting, and by making the minted coin or banknotes proper, or more generally the unit employed in the accounts of the credit institutions, both the medium of exchange and the measure of value-only in this way can the contradiction be overcome and the imperfection be remedied. It is only in this way that a logically coherent credit system, combining both economy of monetary media and stability in the standard of value, becomes in any way conceivable (Wicksell 1975 [1935], 126).

Compared with the previous marginalist scholars, Wicksell had a far better understanding of the endogenous nature of the money supply under a credit-based monetary regime. As a result, his position regarding the validity of the quantity-theoretic use of the 'exchange equation' was closer to the classical banking school, which stated that:

Bank-notes [...] are never issued but on the demand of the recipient parties. New gold coin and new conventional notes are introduced into the market by being made the medium of payments. Bank notes, on the contrary, are never issued but on loan, and an equal amount of notes must be returned into the bank whenever the loan becomes due. Bank-notes never, therefore, can clog the market by their redundance, nor afford a motive to any one to pay them away at a reduced value in order to get rid of them. The banker has only to take care that they are lent on sufficient security, and the reflux and the issue will, in the long run, always balance each other (Fullarton 1845 , 64; italics added).

The main aim of Wicksell was to find a way to stabilize the price level without making recourse to an exogenous money supply. In this regard, he focused directly on the effective demand, identifying the money rate of interest as the instrument through which the banking system influenced the general price level. This influence is triggered by creating a gap between aggregate supply and demand in the market for commodities, which corresponds to a divergence between the money rate of interest and the 'natural' rate of return on capital. The focus on the interest rate was stressed by Wicksell as follows: 
There is a certain rate of interest on loans which is neutral in respect to commodity prices, and tends neither to raise nor to lower them. This is necessarily the same as the rate of interest which would be determined by supply and demand if no use were made of money and all lending were effected in the form of real capital goods. It comes to much the same thing to describe it as the current value of the natural rate of interest on capital (Wicksell 1936 [1898], 102; italics in the original).

Wicksell's method of stabilizing the purchasing power of money was straightforward: the banking system, which possessed the ability to set the money rate of interest, had to adjust the rate to the natural level defined by productivity and thrift. Let us suppose that banks lend money at a rate of interest different from that which corresponds to the current value of the natural rate on capital. In this case,

The economic equilibrium of the system is ipso facto disturbed. If prices remain unchanged, entrepreneurs will in the first instance obtain a surplus profit (at the cost of the capitalists) over and above their real entrepreneur profit or wage. This will continue to accrue so long as the rate of interest remains in the same relative position [...] And the number of people becoming entrepreneurs will be abnormally increased. As a consequence, the demand for services, raw materials, and goods in general will be increased, and the prices of commodities must rise" (Wicksell 1936 [1898], 105-106; italics in the original).

Likewise, if there is an increase in the rate of interest, the opposite situation would occur. Entrepreneurs would suffer losses below their normal incomes as long as prices are stable, hence there would be an incentive to move investment towards more profitable markets. As a consequence there would be an excess supply for goods and services, and the price level would fall (see Wicksell 1936 [1898], 106).

Wicksell's conclusion then was that a paper standard, when administered efficiently, would be superior to any commodity standard in terms of price stability. And to achieve an efficient monetary administration under this regime, the main challenge of monetary policy should be to find the natural level of the interest rate. Wicksell's proposal is clearly an alternative to proposals rooted in the QTM, since it is intended to be independent of any attempt to affect the level of prices through exogenous changes in the quantity of money in the economy. 


\section{CONCLUDING REMARKS}

During the last decades of the 19th century and the beginning of the 20th century, neoclassical economics centred on the question of how to stabilize the price level. Most authors advocated bimetallism, whose theoretical support resided in the validity of the QTM, an account that closed the nominal system with complete independence from general equilibrium barter-exchange models describing the real economy. Yet, contrary to the common belief found in the literature, there are neoclassical authors who proposed alternatives to bimetallism that are independent of the QTM, and which are based on an endogenous view of money. The endogenous dynamics makes these alternative approaches closer to classical views, rather than to the standard neoclassical exogenous view.

In particular, the scope of Marshall's symmetallism is much broader than just a plausible alternative for standard bimetallism. It is the only version of a double standard that could be consistently regarded as stable from a long-period perspective. Alternatively, Fisher's proposal of a compensated dollar is fully compatible with the classical view on commodity standards with seigniorage, and it is fairly independent of the QTM. Finally, Wicksell's approach presents several coincidences with the endogenous money view of the classical banking school. One merit of Wicksell is that he changed the focus from the quantity of money to the rate of interest as the main instrument of monetary policy. A corollary of the analysis presented in this article is that the neutrality of money does not necessarily imply the QTM, as frequently suggested.

\section{REFERENCES}

Caminati, Mauro. 1981. The theory of interest in the classical economists. Metroeconomica, 33 (1-2-3): 79-104.

Cassel, Gustav. 1920. Further observations on the world's monetary problem. The Economic Journal, 30 (117): 39-45.

Dimand, Robert. 2000. Irving Fisher and the quantity theory of money: the last phase. Journal of the History of Economic Thought, 22 (3): 329-348.

Eatwell, John. 1977. The irrelevance of returns to scale in Sraffa's analysis. Journal of Economic Literature, 15 (1): 61-68.

Fisher, Irving. 1894. The mechanics of bimetallism. The Economic Journal, 4 (15): 527537.

Fisher, Irving. 1997 [1913]. The purchasing power of money. In The works of Irving Fisher, ed. William J. Barber. London: Pickering and Chatto.

Fullarton, John. 1845. On the regulation of currencies. London: John Murray. 
Jevons, William Stanley. 1886 [1881]. Bimetallism. Contemporary Review, May. Reprinted in The bimetallic controversy, eds. H. Gibbs, and R. Grenfell. London: Effingham Wilson, Royal Exchange.

Garegnani, Pierangelo. 1976. On a change in the notion of equilibrium in recent work on value and distribution. In Essays in modern capital theory, eds. M. Brown, K. Sato, and P. Zarembka. Amsterdam: North Holland Publishing Company.

Garegnani, Pierangelo. 1984. Value and distribution in the classical economists and Marx. Oxford Economic Papers, 36 (2): 291-325.

Garegnani, Pierangelo. 1990. Quantity of capital. In The New Palgrave: Capital Theory, eds. J. Eatwell, M. Milgate, and P. Newman. London: W. W. Norton \& Co.

Graham, Benjamin. 1937. Storage and stability. New York: McGraw-Hill.

Graham, Frank. 1949. Social goals and economic institutions. New Jersey: Princeton University Press.

Gibbs, Henry H. 1886 [1881]. The double standard. In The bimetallic controversy, eds. H. Gibbs, and R. Grenfell. London: Effingham Wilson, Royal Exchange.

Humphrey, Thomas. 2004. Alfred Marshall and the quantity theory of money. Federal Reserve Bank of Richmond, Working Paper No. 04-10. Richmond, VA.

Keynes, John Maynard. 1971 [1926]. A tract on monetary reform. In The collected writings of John Maynard Keynes, vol. IV. London: Macmillan.

Laidler, David. 2004. From bimetallism to monetarism: the shifting political affiliation of the quantity theory. In Political events and economic ideas, eds. I. Barens, V. Caspari, and B. Schefold. Cheltenham: Edward Elgar.

Laughlin, J. Laurence. 1896. The history of bimetallism in the United States. New York: D. Appleton \& Co.

Laughlin, J. Laurence. 1909. Gold and prices, 1890-1907. The Journal of Political Economy, 17 (5): 257-271.

Lewis, Gilbert. 1925. A plan for stabilising prices. The Economic Journal, 35 (137): 4046.

Lloyd, T. 1894. Bimetallism examined. London: Statist Press.

Marshall Alfred. 1923 [1887]. Remedies for fluctuations in general prices. In Memorials of Alfred Marshall, ed. Arthur C. Pigou. London: Macmillan.

Niehans, Jürgen. 1978. The theory of money. Baltimore and London: The Johns Hopkins University Press.

Patinkin, Don. 1948. Relative prices, Say's law, and the demand for money. Econometrica, 16 (2): 135-154.

Patinkin, Don. 1965. Money, interest, and prices: an integration of monetary and value theory, 2nd ed. [abridged]. Cambridge (MA): The MIT Press.

Patinkin, Don. 1993. Irving Fisher and his compensated dollar plan. Federal Reserve Bank of Richmond Economic Quarterly, 79 (3): 1-34.

Ricardo, David. 2004 [1810-1811]. High price of bullion: a proof of the depreciation of bank notes. In The works and correspondence of David Ricardo, vol. IV, ed. Piero Sraffa. Indianapolis: Liberty Fund.

Rostow, W. W. 1947. British economy of the nineteenth century. Oxford: Clarendon Press.

Sraffa, Piero. 1960. Production of commodities by means of commodities. Cambridge (UK): Cambridge University Press. 
Taussig, Frank. W. 1913. The plan for a compensated dollar. The Quarterly Journal of Economics, 27 (3): 401-416.

Walras, León. 1977 [1874]. Elements of pure economics, translated by William Jaffe. New Jersey: Augustus M. Kelly.

Walras, León. 2005 [1884]. Studies in applied economics: theory of the production of social wealth, vol. 1. London: Routledge.

Wicksell, Knut. 1936 [1898]. Interest and prices. New York: Sentry Press.

Wicksell, Knut. 1975 [1935]. Lectures on political economy, vol. II. New Jersey: Augustus M. Kelley.

Germán D. Feldman received his doctoral degree in economics from the Goethe University Frankfurt. He is professor of macroeconomics at the National University of Quilmes and works as advisor to the UnderSecretary of Economic Policy at the Ministry of Economy and Finance of Argentina. His research focuses on monetary theory and policy, classical economics, and history of economic thought.

Contact e-mail: <feldmangerman@gmail.com> 